Article

\title{
Effects of the duration of breastfeeding and partner support for breast- feeding mothers on the nutritional status of infants aged 0-6 months
}

\author{
Dwi Kartika Yunita, ${ }^{1}$ Tri Budiati ${ }^{2}$ \\ ${ }^{1}$ Faculty of Nursing, Universitas Indonesia, Depok, West Java; ${ }^{2}$ Department of Maternity Nursing, Faculty of \\ Nursing, Universitas Indonesia, Depok, West Java, Indonesia
}

\begin{abstract}
Background: Exclusive breastfeeding is influenced by several things, including the mother's motivation and supporting factors such as husband' support. Exclusive breastfeeding and duration of breastfeeding may relate to nutritional status of infants considering the effects that malnutrition may have. The purpose of this study is to identify the effects the duration of breastfeeding and partner support for breastfeeding mothers on the nutritional status of infants aged 0-6 months in the village of Tanjung Pauh, West Sumatera, Indonesia.

Design and Methods: This study used a quantitative study in which a cross-sectional method. Data collection was carried out using an online questionnaire distributed to the 76 breastfeeding mothers were conducted by consecutive sampling at Tanjung Pauh. Chi-square test analysis was used to determine the association between the duration of breastfeeding and partner support with the nutritional status of infants.

Results: There was not a significant relationship found between the duration of breastfeeding $p=0.216, \alpha=0.05, p>\alpha$ ), and partner support for breastfeeding mothers with the nutritional status of infants aged 0-6 months in the village of Tanjung Pauh, West Sumatera $(p=0.100, \alpha=0.05, p>\alpha)$.

Conclusions: In Tanjung Pauh, partner support is not a factor that affects the nutritional status of infants aged 0-6 months, which may be due to the positive attitude of breastfeeding mothers toward fulfilling their babies' nutritional requirements so as to achieve a normal nutritional status.
\end{abstract}

\section{Introduction}

One of the main goals in Indonesia is to keep the breastfeeding rates in line with the nutritional standards for infants aged 0-6 months. These standards are based on the 2006 WHO growth criteria, which set the growth standards for children aged 0-60 months. Such standards are based on the cases of breastfed infants and properly fed children of different ethnicities who have been raised under optimal conditions and are assessed in a standard way on the basis of their body weight and height. ${ }^{1}$

Achieving a good nutritional status in children, especially in infants under 2 years old is expected to reduce the incidence of stunting, underweight, and wasting, which are considered the main nutrition-associated problems in Indonesia. ${ }^{2}$ According to Basic Health Research (Riskesdas), the rate of severe malnutrition in infants aged 0-23 months in Indonesia is 3.8\%, moderate malnutrition rate of $11.4 \%$. Similarly condition in West Sumatera: $3.9 \%$ of infants aged $0-23$ months suffer from severe malnutrition, $13.0 \%$ suffer from moderate malnutrition. Some provinces have an even higher percentage. For example, in East Nusa Tenggara, $6.9 \%$ of infants aged $0-23$ months suffer from moderate malnutrition, $17.6 \%$ suffer from severe malnutrition. This figure is considered much higher than the average percentage of malnourished children under 5 years of age that has been reported in Indonesia in $2018 .{ }^{3,4}$ According to a literature study that was performed until February 2020 at the sub province Tanjung Pauh Community Health Center, $2.7 \%$ infants aged 0-23 months suffer from moderate malnutrition.

A high rate of exclusive breastfeeding for infants aged 0-6 months may act as an indicator for the fulfillment of the body weight and height requirements for infants aged 0-6 months, which can in turn determine the infant's nutritional status. It should be noted that the nutritional status of infants aged $0-60$ months is assessed according to their body weight with respect to age, height with respect to age, and weight with respect to height. ${ }^{4}$ However, exclusive breastfeeding, which can be helpful for the growth of infants aged 0-6 months, depending on their age, is strongly influenced by several factors, such as the duration of breastfeeding and partner support for breastfeeding mothers. In some regions, such as West Java, the rate of exclusive breastfeeding remains low, especially for postcesarean mothers who are influenced by culture, values, and partner and family support. ${ }^{5}$

Hence, it is important to monitor the early nutritional status of infants considering the effects that malnutrition may have. One type of malnutrition is stunting, which is characterized by a shorter height than that of other children of the same age. Generally, stunted children are more susceptible to diseases and, as adults,

Significance for public health

A high rate of exclusive breastfeeding for infants aged 0-6 months may act as an indicator for the fulfillment of body weight and height requirements for infants aged 0-6 months, which can in turn determine the infant's nutritional status. The nutritional status of infants aged 0-60 months is assessed according to their body weight with respect to age, height with respect to age, and weight with respect to height. However, exclusive breastfeeding, which can be helpful for the growth of infants aged 0-6 months, depending on their age, is strongly influenced by several factors, such as the duration of breastfeeding and partner support for breastfeeding mothers. The aim of this study is to examine the effects of the duration of breastfeeding and partner support for breastfeeding mothers on the nutritional status of infants aged 0-6 months in the village of Tanjung Pauh, West Sumatera, Indonesia. 
are at a higher risk of developing degenerative diseases. Stunting can also affect the level of intelligence of children. ${ }^{6}$ Globally, $45 \%$ of the cases of child mortality (those who are under 5 years of age) are due to various forms of malnutrition, of which stunting is a dominant contributor. ${ }^{7}$

The aim of this study is to examine the effects of the duration of breastfeeding and partner support for breastfeeding mothers on the nutritional status of infants aged 0-6 months in the village of Tanjung Pauh, West Sumatera, Indonesia. The novelty of this study lies in the fact that not many studies have linked the duration of breastfeeding (in minutes) to the nutritional status of infants aged 0-6 months. In fact, the available literature usually only links the duration of breastfeeding to the infant's weight gain and links partner support to the rate of exclusive breastfeeding.

\section{Design and Methods}

This is a quantitative study in which a cross-sectional approach was adopted along with consecutive sampling. The sample included in this study comprised mothers who breastfeed their babies and have partners who are considered part of the selected population, all in line with the inclusion criteria set by the researcher. Sampling was performed using a consecutive sampling method in accordance with the criteria set by the researcher. ${ }^{8}$ Data were collected through a questionnaire filled out by the respondents online, that all participants must read the explanation of the research; 101 participants was participated but 25 were excluded from the study because the ages of their babies were beyond the study threshold and the data they filled in were inaccurate.

\section{Results}

Table 1 shows the results obtained in this research with regard to the nutritional status of infants aged 0-6 months in the village of Tanjung Pauh. As seen in the table, the nutritional status of infants aged 0-6 months in Tanjung Pauh was mostly normal (72.4\%).

\section{Relationship between the duration of breastfeeding and nutritional status}

The results outlined in Table 2 show that respondents who reported breastfeeding their babies for 10-15 min had babies with a normal nutritional status $(32.9 \%)$. Fisher's exact test was performed because the contingency table was larger than $2 \times 2$. The results obtained from the relationship test between the duration of breastfeeding and nutritional status revealed a p-value of 0.216 , which is greater than 0.05 (95\% confidence interval [CI]), hence failing to reject the null hypothesis. Therefore, no statistically significant relationship was found between the duration of breastfeeding and the nutritional status of infants aged 0-6 months in the village of Tanjung Pauh, West Sumatera.

\section{Relationship between partner support and nutritional status}

The results outlined in Table 3 show that most of the respondents received adequate partner support (88.1\%). Fisher's exact test was again performed here because the contingency table was larger than $2 \times 2$, with one cell having an expectation value of less than 5 . The results obtained from the relationship test between partner support for breastfeeding mothers and nutritional status revealed a p-value of 1.000 , which is again greater than $0.05(95 \%$ $\mathrm{CI})$, hence failing to reject the null hypothesis. Therefore, no statistically significant relationship was found between partner support for breastfeeding mothers and the nutritional status of infants aged 0-6 months in Tanjung Pauh, West Sumatera.

Table 1. Distribution of infants according to their nutritional status $(\mathbf{n}=76)$.

\begin{tabular}{lll} 
Nutritional status & n & $\%$ \\
Normal & 55 & 72.4 \\
Abnormal & 21 & 27.6 \\
\hline Total & 76 & 100 \\
\hline
\end{tabular}

Table 2. Relationship between the duration of breastfeeding and nutritional status $(n=76)$.

\begin{tabular}{|c|c|c|c|c|c|}
\hline \multirow[t]{3}{*}{ Duration of breastfeeding } & \multicolumn{4}{|c|}{ Nutritional status } & \multirow[t]{3}{*}{ p } \\
\hline & & & & & \\
\hline & n & $\%$ & n & $\%$ & \\
\hline$<5$ min on each breast & 1 & 1.3 & 1 & 1.3 & 0.216 \\
\hline 5-10 min on each breast & 18 & 23.7 & 11 & 14.5 & 0.216 \\
\hline 10-15 min on each breast & 25 & 32.9 & 5 & 6.6 & 0.216 \\
\hline 15-30 min on each breast & 11 & 14.5 & 4 & 5.3 & 0.216 \\
\hline
\end{tabular}

Table 3. Relationship between partner support and nutritional status.

\begin{tabular}{|c|c|c|c|c|c|}
\hline \multirow[t]{3}{*}{ Partner support } & \multicolumn{4}{|c|}{ Nutritional status } & \multirow[t]{3}{*}{ p } \\
\hline & & & & & \\
\hline & n & $\%$ & $\mathrm{n}$ & $\%$ & \\
\hline Adequate & 48 & 63.1 & 19 & 25 & 1.000 \\
\hline Inadequate & 7 & 9.2 & 2 & 2.6 & 1.000 \\
\hline Total & 55 & 72.3 & 21 & 27.6 & 1.000 \\
\hline
\end{tabular}




\section{Discussion}

\section{Relationship between the duration of breastfeeding and nutritional status}

Although the results obtained in this study are not supported by previous research with the same variables, several studies related to this one are available. For example, according to Susanti, Kartika, and Hadju, in Makassar, South Sulawesi, Indonesia, the duration of breastfeeding affects the rate of malnutrition in children aged 6-24 months, which reveals a significant relationship between these two factors. Such a relationship can also be observed in toddlers who are breastfed for an average of less than 10 min per feeding, who exhibit a 3.75 -fold higher risk of malnutrition than toddlers who are breastfed for $10 \mathrm{~min}$ or more per feeding. ${ }^{9}$

Another study in this area supporting the results obtained here is that of Hikmah, who investigated the relationship among the history of breastfeeding, formula milk, and complementary feeding in Majalengka, a town in West Java, Indonesia, in children under 5 years of age with a risk of overnutrition. ${ }^{10}$ According to Hikmah, none of the categories in the history of breastfeeding exhibited a significant relationship with the nutritional status of children under 5 years of age, as measured by the body mass index. It should be noted that one of the categories in the history of breastfeeding is the duration of breastfeeding. From the results, no statistically significant relationship was found between the duration of breastfeeding and nutritional status in this study. ${ }^{10}$

The results of this study may be due to some factors that affect the smooth production of breast milk, which can help achieve exclusive breastfeeding for six months so that the baby can grow and develop properly. Budiati said that mother habits influencing the continuity of breastfeeding. ${ }^{11}$ According to Dewi, several factors are closely related to the smooth production of breast milk, such as the mother's mental peace, nutrition, and rest; baby suction; use of contraception; and breast care. ${ }^{12}$ The habits of Minangkau community also may influence this research. Some of the respondents (mothers) belonged, which include eating savory and spicy foods. These types of food are usually made from a mixture of coconut milk and chilies. The Minangkabau people also have a preference for processed meat, and their diet usually contains meat. Both processed coconut milk and meat contain cholesterol, which causes weight gain if consumed in large amounts.

According to Isganaitis et al., ${ }^{13}$ being overweight affects milk metabolism in breastfeeding mothers. Since the metabolism of breast milk is related to maternal and infant weight, there is a potential relationship between breast milk and the transmission of obesity to the mother and child. In that study, 10 different metabolites were found in obese breastfeeding mothers with normalweight mothers. Three of these metabolites are complex carbohydrates that affect the microbiota of the baby's intestine. In infants aged 0-6 months, however, 20 metabolites were found. The results obtained in that study show that the mother's weight and health greatly affect the nutritional value of breast milk. ${ }^{13}$

\section{Relationship between partner support and nutritional status}

Many previous studies have shown that partner support for breastfeeding mothers is associated with exclusive breastfeeding. Preliminary research conducted by Budiati, on 148 postoperative cesarean mothers showed that 84 percent of post SC mothers had excellent knowledge regarding exclusive breastfeeding, but only 23.3 percent gave exclusive breastfeeding, one factor what affected him was the lack of support from the couple. ${ }^{5}$ In a study by Larasati in Bantul, a regency located in the Yogyakarta Special Region, Indonesia, on the relationship between partner support and the success of exclusive breastfeeding, a significant relationship was found between these two factors. ${ }^{14}$ Moreover, in a study performed in the Umbulharjo Community Health Center work area 1 in 2017, Rosinta pointed out that partner support for breastfeeding mothers is significantly associated with successful exclusive breastfeeding. ${ }^{15}$

Several studies related to this research are available in the literature. For example, in a study on the relationship between family support and the nutritional status of children under 5 years of age in Central Java, the results revealed a significant relationship between these two factors. In general, toddlers whose mothers receive optimal family support are 0.020 times more likely to have a better nutritional status than when mothers do not receive adequate family support. ${ }^{16}$

However, it should be noted that the above research emphasizes that such family support is provided by the mother's family, such as the grandmother, who helps take care of the toddlers and also helps the mother get through difficult times. Moreover, toddlers are children who are 24-59 months of age; hence, the results obtained in this study cannot be used as a reference for the effect of partner support on the nutritional status of infants aged 0-6 months.

It should also be pointed out that the results obtained in this study are different from those of Lisa, who performed a study in Pidie Jaya Regency on the relationship between family support for breastfeeding mothers and the nutritional status of infants aged 0 6 months. The results obtained in that study revealed a significant relationship between these two factors. ${ }^{17}$

A study of predictors of breastfeeding plans among lowincome women found that perceptions of social support significantly strengthened the intention to breastfeed. ${ }^{18}$ The different results of this study and previous ones may be due to the differences between the research subjects. For instance, this study was performed within the village of Tanjung Pauh, where most of the population are Minangkabau people $(86.8 \%)$. The Minangkabau people generally adopt a matrilineal system, which regards the role of the mother(woman) to be quite important within the family, such as someone who organize inheritance, hence largely influencing the results obtained herein. ${ }^{19}$

In matrilineal families, mothers and partners always discuss the decisions to be taken, and the breastfeeding mother has the right to decide on breastfeeding her baby. However, the husband is the one of the necessary supporting factors because of its emotional closeness to the mothers. In addition, breastfeeding mothers are usually aware of the needs of their babies, with or without their partner's support, because they have more power and more educated so they can decide by her what they need for their baby. This is related to the attitude of the mother toward exclusive breastfeeding. Wenas performed a study in the district of Tompaso on the relationship between the knowledge and attitude of breastfeeding mothers and exclusive breastfeeding. The results obtained showed that the attitude of breastfeeding mothers is significantly related to exclusive breastfeeding. Self-confidence of mothers influenced them to make a decision. ${ }^{20}$

Another study that proves the importance of the attitude of breastfeeding mothers in the practice of exclusive breastfeeding is that by Hargi. This study was performed in Jember Regency, and the results obtained showed that breastfeeding mothers who have a positive attitude toward exclusive breastfeeding are more likely to exclusively breastfeed their babies. ${ }^{21}$ 


\section{Conclusions}

Having a positive attitude encourages breastfeeding mothers to meet the nutritional needs of their babies so as to help them achieve a normal nutritional status. Therefore, it was found that, in Tanjung Pauh, partner support is not a factor that affects the nutritional status of infants aged 0-6 months, which may be due to the positive attitude of breastfeeding mothers toward fulfilling their babies' nutritional requirements so as to achieve a normal nutritional status.

Correspondence: Tri Budiati, Department of Maternity Nursing, Faculty of Nursing, Universitas Indonesia, Jalan Prof. Dr. Bahder Djohan, UI Depok Campus, West Java 16424, Indonesia.

Tel. +62.21.78849120 - Fax: +62.21.7864124.

E-mail: t-budiati@ui.ac.id

Key words: Duration of breastfeeding; fathers' support; nutritional status of infants aged 0-6 months.

Contributions: All authors contributed equally. TB, supervised conceptualization and design the study, revising it critically for important intellectual content, final approval; DKY, concept and design analysis and interpretation of data, drafting manuscript.

Conflict of interest: The authors declare no conflict of interest, financial or otherwise.

Acknowledgments: The author wish to thank all the respondents and parties who had helped the completion of this research. Our deepest gratitude was also expressed to the Direktorat Riset dan Pengembangan Universitas Indonesia for funding this research with fund PUTI Prosiding 2020 Number: NKB-3423/UN2.RST/HKP. $05.00 / 2020$

Ethics approval and consent to participate: This study has been approved by Ethics Committee of Faculty of Nursing Universitas Indonesia, Depok with Number: SK-267/UN2.F12.D1.2.1/ETIK 2020. For respondent who participated in the research, fill out the informed consent form.

Availability of data and materials: The datasets analyzed in this study are available from the corresponding author on reasonable request.

Conference presentation: This final manuscript has been presented at $7^{\text {th }}$ Virtual Biennial International Nursing Conference, Faculty of Nursing, Universitas Indonesia on September $24^{\text {th }}$, October $30^{\text {th }}$, November $16^{\text {th }} 2020$.

Received for publication: 31 July 2020.

Accepted for publication: 7 May 2021

o Copyright: the Author(s), 2021

Licensee PAGEPress, Italy

Journal of Public Health Research 2021; 10(s1):2400

doi:10.4081/jphr.2021.2400

This work is licensed under a Creative Commons Attribution

NonCommercial 4.0 License (CC BY-NC 4.0).

\section{References}

1. WHO, UNICEF. WHO child growth standards and the identification of severe acute malnutrition in infants and children. World Health Organization; 2009 Accessed on: 2020 February. Available from https://apps.who.int/iris/ bitstream/handle/10665/44129/9789241598163_eng.pdf?ua=1

2. Ministry of Health, Republic of Indonesia. [Warta KESMAS: gizi, investasi masa depan bangsa (Public health news: Nutrition, investment in the future of the nation)].[in Indonesian] Jakarta: Ministry of Health Republic of Indonesia; 2017. Available from: http://kesmas.kemkes.go.id/ assets/upload/dir_519d41d8cd98f00/files/Warta-KesmasEdisi-02-2017_898.pdf

3. Ministry of Health Republic of Indonesia. [Hasil utama Riskesdas 2018 (Main results of Basic Health Research 2018)].[in Indonesian]. Jakarta: Ministry of Health Republic of Indonesia; 2018. Available from: https://kesmas.kemkes.go.id/ assets/upload/dir_519d41d8cd98f00/files/Hasil-riskesdas2018_1274.pdf

4. Ministry of Health Republic of Indonesia. [Data dan informasi: profil kesehatan Indonesia 2018 (Data and information: Indonesia's health profile 2018)].[in Indonesian]. Jakarta: Ministry of Health Republic of Indonesia; 2019. Available from: https://pusdatin.kemkes.go.id/resources/download/pusdatin/profil-kesehatan-indonesia/Data-dan-Informasi_ProfilKesehatan-Indonesia-2018.pdf

5. Budiati T, Setyowati. The influence culture and maternal care on exclusive breastfeeding practice in post caesarean section mothers. Enferm Clin 2019;29:808-14.

6. Ministry of Health Republic of Indonesia. [Situasi Balita Pendek (Stunting) di Indonesia (The situation of stunting in Indonesia)].[in Indonesian]. Jakarta: Data and Information Center Ministry of Health Republic of Indonesia; 2018. Available from: https://pusdatin.kemkes.go.id/download. php? file=download/pusdatin/buletin/Buletin-Stunting2018.pdf

7. Oot L, Sethuraman K, Ross J, Sommerfelt AE. The effect of chronic malnutrition (stunting) on learning ability, a measure of human capital: a model in PROFILES for country-level advocacy. Washington: FHI 360/FANTA.

8. Notoadmodjo S. [Metodologi penelitian kesehatan (Health research methodology)].[Book in Indonesian]. Jakarta: Rineka Cipta; 2010.

9. Susanty M, Kartika M, Hadju V, Alharini S. [Hubungan pola pemberian ASI dan MP ASI dengan buruk pada anak 6-24 bulan di Kelurahan Pannampu Makassar (The relationship between breastfeeding patterns and complementary breastfeeding is poor for children 6-24 months in Pannampu Village, Makassar)].[Article in Indonesian]. Jurnal Media Gizi Masyarakat Indonesia 2012;1:97-103.

10. Hikmah N. [Riwayat pemberian ASI, susu formula, dan MP ASI pada anak balita dengan risiko gizi lebih di Kecamatan Majalengka (History of breastfeeding, formula milk, and complementary breastfeeding for children under five with a risk of over nutrition in Majalengka District)].[Thesis in Indonesian]. Bogor: Institut Pertanian Bogor; 2016.

11. Budiati T, Setyowati, Daulima NHC. [Peningkatan produksi ASI ibu nifas seksio sesaria melalui pemberian paket "sukses ASI" (Increased production of breastmilk for post-partum cesarean mothers through the provision of "successful ASI" packages)].[Article in Indonesian]. Jurnal Keperawatan Indonesia 2010;2:59-67.

12. Dewi ADC. [Faktor-faktor yang mempengaruhi kelancaran produksi ASI (Factors that affect the smooth production of breast milk)].[Article in Indonesian]. Jurnal 'Aisyiyah Medika 2019;4:22-34.

13. Isganaitis E, Venditti S, Matthews TJ, et al. Maternal obesity and the human milk metabolome: associations with infant body composition and postnatal weight gain. Am J Clin Nutr 
2019;110:111-20.

14. Larasati PA. [Hubungan dukungan suami dengan keberhasilan ASI ekslusif di wilayah kerja Puskesmas Jetis II Bantul (The relationship between husband's support and the success of exclusive breastfeeding in the working area of Puskesmas Jetis II Bantul)].[Thesis in Indonesian]. Yogyakarta: Universitas 'Aisyiyah; 2017.

15. Rosinta NA. [Hubungan dukungan sosial suami dengan pemberian ASI ekslusif di wilayah kerja Puskesmas Umbulharjo I Yogyakarta (The relationship between husband's social support and exclusive breastfeeding in the working area of Puskesmas Umbulharjo I Yogyakarta)].[Thesis in Indonesian]. Yogyakarta: Politeknik Kesehatan Kementerian Kesehatan; 2019.

16. Latifah N, Susanti Y, Haryanti D. [Hubungan dukungan keluarga dengan status gizi pada balita (The relationship between family support and nutritional status of children under five)].[Article in Indonesian]. Jurnal Keperawatan 2018;10:68-74.

17. Lisa UF, Ariza C. [Hubungan dukungan keluarga dan pemberian ASI dengan status gizi bayi 0-6 bulan di wilayah kerja Puskesmas Trienggadeng Kabupaten Pidie Jaya Tahun 2016 (Relationship between family support and breastfeeding with the nutritional status of infants $0-6$ months in the working area of Trienggadeng Health Center, Pidie Jaya Regency,
2016)].[Article in Indonesian]. J Healthcare Technol Med 2017;3:209-19.

18. Chezem J, Friesen C, Boettcher J. Breastfeeding knowledge, breastfeeding confidence, and infant feeding plans: effects on actual feeding practices. J Obstet Gynecol Neonatal Nurs 2003;321:40-7.

19. Selinaswati. Women in politics in matrilineal society: a case study of West Sumatera, Indonesia. [PhD Dissertation]. Melbourne: Deakin University; 2014.

20. Wenas W. [Hubungan antara pengetahuan dan sikap ibu menyusui dengan pemberian AIR susu ibu ekslusif di wilayah kerja Puskesmas Tompaso Kecamatan Tompaso (The relationship between knowledge and attitudes of breastfeeding mothers with exclusive breastfeeding in the working area of Tompaso Community Health Center, Tompaso District)].[Thesis in Indonesian]. Manado: Universitas Sam Ratulangi; 2012.

21. Hargi JP. [Hubungan dukungan suami dengan sikap ibu dalam pemberian ASI ekslusif di wilayah kerja Puskesmas Arjasa Kabupaten Jember (The relationship between husband's support and mother's attitude in exclusive breastfeeding in the working area of Arjasa Health Center, Jember Regency)].[Thesis in Indonesian]. Jember: Universitas Jember; 2013. 